\title{
Natural-Born Subjects? Race and British Subjecthood in Australia
}

\begin{abstract}
John Chesterman
From the time of European settlement in Australia until 1948, British subjecthood was the preeminent Australian citizenship classification. "Australian citizenship" was only created as a legal category in 1948, and from then until 1984 British subjecthood continued to exist, alongside Australian citizenship, as a kind of parenthetical citizenship status. This article explores the meanings and significance of British subjecthood in Australia, and considers the reasons for its eventual demise. The article argues that the advent of formal (legal) racial equality in Australia for Indigenous people and for immigrant groups (which culminated in 1975 with the passage of the Racial Discrimination Act), was one significant factor that helped to render obsolete the scenario whereby Australian citizens were deemed also to be British subjects.
\end{abstract}

One of the most famous, and in some ways illustrative, references to British subjecthood in nineteenth century Australia was made by a man named Jemmy Morrill (also known as James Murrells). Morrill, who provided the seed for the central character, Gemmy, in David Malouf's Remembering Babylon, had been shipwrecked in the mid nineteenth century and reportedly lived for seventeen years with one or more Aboriginal groups around what is now Townsville in north Queensland. According to a publication purporting to be his memoirs, Morrill one day appeared at the fence of a group of settlers, and when confronted with a rifle, he called out:

"Do not shoot me, I am a British object — a British sailor." I meant, of course, subject, but in my excitement, and forgetting the proper word, I hardly knew what to say.

The significance here of British subjecthood is that, even after years in the harsh colonial Queensland frontier, one's British subjecthood would provide a level of protection.

British subjecthood, of course, long pre-dated European settlement of Australia. One of the clearest legal statements concerning subjecthood dates back to Calvin's Case of 1608, where the distinction was made between those who are born as aliens and those who are born as subjects. The main criteria that needed to exist for a person to be born a subject were that the birth took place in the "King's dominion", and that the parents were "under the actual obedience of the King". The division between subjects and aliens is one that has existed for most of the time in which Europeans have been in Australia.

Colonial legislatures in Australia, as soon as they enacted naturalisation statutes enabling aliens to remain in their colonies, adopted British subjecthood as the way to describe the new status of those who had been naturalised. One Western Australian statute of 1841 declared a person so naturalised as "enabled to purchase and hold Lands, and to enjoy all the other Privileges of a natural born British Subject within the Limits of the Colony of Western Australia".

With the establishment of the Commonwealth of Australia in 1901 British subjecthood immediately became enshrined in Commonwealth law. Section 117 of the Australian Constitution contained (and still contains) one of the few, albeit confusing, constitutional statements on rights. It states that a "subject of the Queen" 
cannot be discriminated against on the basis of his or her state of residence.

The first Commonwealth naturalisation law provided that:

A person to whom a certificate of naturalization is granted shall in the Commonwealth be entitled to all political and other rights powers and privileges and be subject to all obligations to which a natural-born British subject is entitled or subject in the Commonwealth.

But what were these "rights powers and privileges [...] to which a natural-born British subject is entitled"? This is the first of two questions that I want to address in this article. The second, is how should we understand the ultimate demise of British subjecthood in Australia?

\section{Acquiring British Subjecthood}

To be recognised as a British subject in Australia in the first half of the twentieth century one had to be born in Australia, be recognised as a British subject in another Commonwealth country, or be naturalised according to Australian naturalisation laws.

To be sure, British subjecthood, at least for people born in Australia, was a status one acquired without racial qualification. People who were born in Australia were, more or less, automatically British subjects. There was never any doubt that Indigenous Australians were British subjects. They were British subjects by virtue of being born in Australia. Geoffrey Sawer argued in 1961 that:

It is clear that $[\ldots]$ every aboriginal native of Australia born in Australia after 1829 (by which date the whole of the continent was part of the dominions of the Crown) became a British subject by birth; his race was irrelevant, and there were no other circumstances capable of qualifying the allegiance.

British subjects, meanwhile, from outside Australia had to negotiate Australia's White Australia Policy, which restricted immigration on the basis of race. But those non-Australian British subjects who managed to get inside Australia continued to be recognised as British subjects. Thus Indians, for instance, who managed to immigrate to Australia were recognised as British subjects in Australia.

For aliens who managed to negotiate Australia's racist immigration policies and arrive in Australia, the Naturalization Act from 1903 prevented certain "aboriginal native[s]" from being naturalised, and thus prevented these immigrants from enjoying the status of British subject in Australia. This changed in 1920, in keeping with British law, when specific racial qualifications were removed from Australia's naturalisation law. The Nationality Act 1920, under which aliens could seek British subject status in Australia, merely stated that applicants had to show that they had "resided in His Majesty's dominions" for five years, were "of good character" and had "an adequate knowledge of the English language" to be entitled to the rights of "a natural-born British subject". ${ }^{8}$ Clearly these requirements allowed a degree of administrative discretion that enabled racial criteria to constitute grounds for denying naturalisation applications, a point borne out by contemporaneous archival documents from the Department of Home and Territories, which showed racial factors regularly to be given consideration in the exercise of administrative discretion over the granting of naturalisation. But from 1920 the law, if not the practice, provided no colour bar to prevent alien immigrants from seeking naturalisation and the rights of "a natural-born British subject". But what were these so-called rights? What rights did one acquire upon achieving British subject status in Australia?

\section{The Effects of British Subjecthood}

When Australia passed its first national naturalisation law, the meaning and effect 
of British subjecthood was unclear. The Postmaster General, during debates on the naturalisation bill, argued that: "The particular rights and privileges of British subjects as against aliens is a matter that is not very clear in any British country."

In short, a person's status as a British subject in Australia entitled them to very few legal rights. Entitlements that one might see as naturally flowing from British subject status - such as the right to vote and receive social security - did not follow automatically upon a person being recognised as a British subject in Australia. The criteria that needed to be satisfied for these rights to be enjoyed were contained in a number of different pieces of legislation. Subject status was a threshold that needed to be met in order for these rights to be enjoyed, but it did not guarantee enjoyment of these rights.

The first national franchise legislation, for instance, stated that in order to be eligible to vote in federal elections people had to be "natural born or naturalized subjects of the King". But many British subjects, particularly non-white ones such as Indigenous Australians and Indians, were specifically denied entitlements by provisions in a range of racially discriminatory legislation. Until 1925, Commonwealth electoral law prevented any "aboriginal native of Australia, Asia, Africa, or the Islands of the Pacific (except New Zealand)" from voting. ${ }^{12}$ This included Indians and Aboriginal Australians (and in World War I even some otherwise eligible naturalised subjects were specifically denied the vote if they had been "born in an enemy country". ') In 1925 international lobbying saw Indians gain the national vote in Australia, though it was not until 1962 that all adult Indigenous Australians won the national vote.

As Geoffrey Sawer argued in 1961:

Being a British subject is by itself worth little; it is the foundation on which further conditions of disqualification or qualification are built, such as being a member of a particular race or meeting residential requirements.

One of the few legal benefits to be derived from being a British subject was that one could, in general, avoid being deported to one's country of birth. And even this was not always the case. The Commonwealth Immigration Act and the Crimes Act contained provisions whereby people "not born in Australia" were liable to be deported for treason-like activities. Thus even British subjects born overseas faced possible deportation in some situations. But in general one of the main benefits of subjecthood was that one was immune from deportation.

Given that this was a key benefit of subjecthood, one can understand why Indigenous Australians had more reason than most to query the value of their British subject status. One is reminded here of one of the protests of the Indigenous activist and leader of the self-proclaimed Aboriginal Provisional Government, Michael Mansell. As the story has it, Mansell at least once has presented himself to customs officials in Australia and shown his Aboriginal Provisional Government passport. When greeted with looks of incredulity and told that the APG passport is not recognised in Australia, the story goes, he has responded with words such as "Well, what are you going to do, deport me?"

So, while British subjecthood was not a racially specific category, nor was British subjecthood of much benefit to non-white people in Australia. The only non-white people in Australia who benefited from the status were the few nonwhite aliens who managed to get naturalised and thus avoided being liable for deportation. Aside from this small group, British subjecthood was of no benefit to non-white people in Australia. This was because it was a status that existed alongside a raft of laws and bureaucratic practices that were specifically racist. 
An interesting side point is that not only was British subject status of limited benefit in Australia, but the acquisition of British subjecthood in Australia was not necessarily recognised elsewhere. In 1920 an English court considered the citizenship status of a man who had been naturalised in Australia in 1908. The court found that the fact that the man had become "a naturalized Australian subject of the King [...] does not confer upon him within the United Kingdom the rights of a British subject as such". The man, a naturalised British subject in Australia, was found, therefore, to be an alien so far as the law in the United Kingdom was concerned.

\section{Australian Citizenship}

In 1948 "Australian citizenship" was officially created with the passage of the Nationality and Citizenship Act 1948 (Cth). Although this Act created the new legal entity of "Australian citizenship", the legislation barely changed Australia's naturalisation practices. The division between British subjects and aliens that had existed for the entirety of white settlement in Australia continued to be maintained by the new Act, and indeed the Act specifically stated that any "person who, under this Act, is an Australian citizen [...] shall, by virtue of that citizenship, be a British subject".

As Arthur Calwell, the Minister for Immigration, argued, the citizenship legislation:

[...] is not designed to make an Australian any less a British subject, but to help him to express his pride in citizenship of this great country. That is a pride which is praiseworthy, because it is based on a belief that Australia has done as much as any other British nation to develop, expand and improve the free institutions and systems of organized society that had their origin in the United Kingdom.

Australia was still identified, of course, very strongly as being a British nation, and even those, such as Jack Lang, who sought a more active statement of citizenship rights in the new citizenship legislation, agreed with the retention of British subject status.

From 1949 a person born in Australia automatically (with few exceptions) became an Australian citizen and a British subject. Attorney-General Garfield Barwick defined the dual status in 1959 in this way:

[Australian] citizenship is the only national status which people have in relation to Australia although by dint of our relationship to the Queen and to the British Commonwealth of Nations Australian citizens are also British subjects.

For people born outside Australia, there were two distinct ways in which one could take out Australian citizenship. In the past aliens could become British subjects in Australia by going through naturalisation processes, while British subjects from outside Australia, of course, did not have to do anything in terms of naturalisation processes since they were already British subjects. From 1949 aliens could go through the naturalisation process and acquire Australian citizenship and British subject status, while non-Australian British subjects had merely to register in order to become Australian citizens. ${ }^{22}$ Once again the division between aliens and subjects was a well-defined one. Aliens had to go through naturalisation processes to acquire Australian citizenship, while non-Australian British subjects had merely to register to achieve citizen status.

Another similarity with past practices was that Australian citizenship, like British subjecthood, was of limited legal significance. There were no rights of Australian citizenship, so to speak. While there were no specific racial criteria that needed to be satisfied in order for a person to acquire Australian citizenship, nor did 
Australian citizenship status do anything to improve the position of non-white Australian citizens, who remained subject to racially discriminatory laws and administrative practices. Indigenous Australians constituted the group of Australians against whom the most pernicious racial discrimination was levelled, being the explicit victims of racially discriminatory Commonwealth legislation and quasi-legislation in the fields of access to social security, the franchise, and industrial award protection. So while Indigenous Australians were automatically Australian citizens and British subjects, they were "citizens without rights", a label Brian Galligan and I used as the title for our book on the citizenship status of Indigenous Australians.

There are many examples of the way this status was used conspiratorially against Indigenous Australians. In one instance in 1962, in a bid to hose down burgeoning international concern about Australia's treatment of its Indigenous population, Australian diplomats were advised in the following manner:

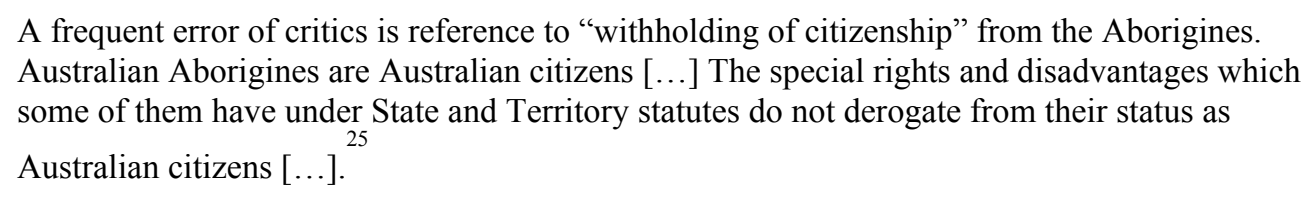

Whilst legally accurate, such an argument was, of course, misleading.

\section{Demise of British Subjecthood in Australia}

For thirty-five years, from 1949 until 1984, people who were classified as Australian citizens were also British subjects according to Australian law. Here I want to examine why the parenthetical status of British subject was ultimately jettisoned by Australian authorities.

The question of why British subject status was removed from Australian citizenship legislation is merely part of the larger question of why Britishness ceased to be a defining quality for many Australians after the Second World War. There are a number of factors that explain why Australians gradually came to the conclusion that, at least in official terms, it made little sense to continue depicting the country and its citizens as part of the British empire (this is a process, of course, that will not be complete until Australia sheds its status as a constitutional monarchy).

In a way, it is fair to argue that British subjecthood eventually became a victim of its own legal insignificance. But this alone is insufficient as a causal explanation. As I have already argued, this legal insignificance existed from 1949, and yet the dual status continued for decades. There exist several other factors that explain why Australian governments would choose less and less to treat Britishness as a dual citizenship category. Many of these reasons have been examined by others, and include: the divergent defence interests of Great Britain and Australia in the middle of the twentieth century, most starkly illustrated by the "Singapore betrayal" in the Second World War; and Britain's economic shift from the 1960s which revealed a closer European focus.

Changes to immigration laws and practices in the United Kingdom in the 1960s also, in their own way, would have added to the sense of estrangement that Australians were increasingly feeling from the United Kingdom. Stuart Ward has recently written about the developments in the mid 1960s that required Australians, like other foreigners, to obtain specific permission to be employed there. This process of estrangement became more pronounced as Australia progressively became depicted as just another foreign country under United Kingdom immigration laws, a move that Ward points out led Australia to cease printing "British Passport" on its travel papers. Ultimately, of course, with the United 
Kingdom's membership of the EEC the key distinction that was made at British airports was not whether one was British, but whether one was European, something even Australians had a hard time claiming.

What I want to argue is that another key factor in this belated decision to abolish British subject status in Australia involved race.

Although British subjecthood was ostensibly a "racially neutral" one, its existence, and even its emotive draw, have to be considered alongside Australia's specifically racist laws and policies, especially the White Australia Policy, and the overt legislative discrimination against Indigenous Australians. While these policies and laws remained in existence, it was possible for British subject status to be seen to unify a displaced white British diaspora. Immigration laws restricted by race those people coming into the country, and racially discriminatory laws ensured a subservient legal status for racial minorities within Australia. The fact that there were some non-white British subjects did not upset too much this sense of British unity, given that there existed other ways of calibrating the level of one's membership of this imagined family. (Indeed, much as Australian citizenship was used as a rhetorical device to hide the subservient legal position of Indigenous Australians, the officially "non-racial" character of British subjecthood gave it a good deal of moral credibility, especially in the outlying parts of the empire.) But the abolition of explicitly racist practices and laws changed forever this calibrated system whereby Australians could also see themselves as possessing some level of Britishness. When there ceased to be a legal way of delineating the degree of one's membership of this imagined family, the family began to lose its relevance.

The abolition of Australia's racially discriminatory laws and practices largely took place in the 1960s and 1970s as the result of domestic and international pressure. Bans on Indigenous people's exercise of the federal franchise were removed in 1962, and bans regarding social security were removed in 1966 . In $^{29}$ 1966, the year that Australia signed the International Convention on the Elimination of All Forms of Racial Discrimination, the White Australia Policy was in the process of being dismantled, and during the ensuing decade the overt racial discrimination contained in the various strands of immigration policy would be removed. $^{30}$ In 1967 a constitutional referendum removed the two references to Aborigines in Australia's Constitution. This shift towards formal racial equality can be seen - at least nationally, if not at State level - to have ended with Australia's ratification of the discrimination convention, and its passage of the Racial Discrimination Act in 1975. (I emphasise that here I am talking about formal racial equality, and not what one might term substantive racial equality.)

It took another nine years until Australia changed the practice whereby British subject status was automatically bestowed on national citizens. From 1984 Australian citizens no longer retained the dual status of British subjects. Introducing this change to parliament, the Minister for Immigration, Stewart West, simply argued:

The common code concept of uniting all Commonwealth countries under the umbrella of British nationality is no longer valid [...] Australia is now the only country in the world to continue to use the concept of British subject status in preference to its own nationality.

This was also the time when other citizenship-related legislation was amended. Until 1984 Australian passports could be issued "to Australian citizens and to British subjects who are not Australian citizens", but the reference to British subjects was dropped in 1984.

Meanwhile, Australian franchise legislation gradually came to terms with the 
changing significance of British subjecthood in Australia. As I wrote earlier, British subjecthood had, since 1902, existed as a threshold criterion that needed to be met before one could exercise the federal vote in Australia. In 1981 an amendment to the franchise legislation began to draw a faint line in the sand, differentiating between Australian citizenship and British subjecthood now for the first time. From 1981 would-be voters had either to be Australian citizens, or already enrolled British subjects, in order to be eligible to vote. This provision was amended slightly in 1985 to the current situation regarding voting eligibility. The provision inserted then, which remains in force, holds that to be eligible to vote in federal elections people must either be Australian citizens or

persons (other than Australian citizens) who would, if the relevant citizenship law had continued in force, be British subjects within the meaning of that relevant citizenship law and whose names were, immediately before 26 January 1984 [on the electoral roll].

So British subjecthood continues to entitle some non-Australian citizens to a federal vote in Australia, a fact that James Jupp refers to as "the largest anomaly in the otherwise rigorously administered compulsory voting system".

Perhaps the final statement on British subjecthood in Australia came in a High Court decision fifteen years after Australian citizens ceased automatically being British subjects. The 1999 case of Sue v Hill concerned a peculiar section of the Australian Constitution, section 44, which states in part:

Any person who:

(i) is under any acknowledgment of allegiance, obedience, or adherence to a foreign power, or is a subject or a citizen or entitled to the rights or privileges of a subject or a citizen of a foreign power $[\ldots]$

shall be incapable of being chosen or of sitting as a senator or a member of the House of Representatives.

Heather Hill stood as a Queensland Senate candidate at the 1998 federal election, representing Pauline Hanson's One Nation Party. Hill held British citizenship, and had recently also taken out Australian citizenship. The question for the High Court of Australia was whether Hill, although an Australian citizen, was in contravention of section 44 and was thus incapable of being elected as a Senator by reason of her being a "citizen $[\ldots]$ of a foreign power".

The High Court found that Hill could not take her place in the Senate. Although she had taken out Australian citizenship, this, according to British law, did not affect her status as a British citizen, and the High Court found that Hill had taken insufficient steps to divest herself of British citizenship. (Although some citizenships are impossible to rescind, the High Court found that people in this situation still must take reasonable steps to divest themselves of these other citizenships if they want to sit in federal parliament.) In addition, and more importantly for present purposes, the High Court found that the United Kingdom constituted a "foreign power". Hill was thus deemed to be a "citizen [...] of a foreign power", and was therefore ineligible to be elected as a Senator.

Perhaps it was fitting that while British nationality was seen by Jemmy Morrill to be a life-saving status on the Queensland frontier in the nineteenth century, that same status should provide no sanctuary at the turn of the twenty-first century for a Queenslander, whose political party, at least in policy terms, was arguably seeking a return to Morrill's frontier.

\section{Conclusion}

In this article I have tracked the changes to the political and legal status of British subjecthood in Australia. It is curious that this status, which for many had such an 
emotive draw, also carried with it a profound sense of legal insignificance. British subject status in Australia did not automatically entitle one to vote or to enjoy any of the benefits or rights that one might normally equate with full membership of a political community.

Things changed very little when Australian citizenship was created as a legal entity in 1948, after which British subjecthood existed as a parenthetical citizenship status until 1984. I discussed a number of reasons why, after 1948, it became ever stranger that Australian citizens were also defined as British subjects. These reasons included legal and social changes both in the United Kingdom and Australia that increasingly depicted the other as a foreign country with its own national interests to pursue.

I have argued that another reason why British subjecthood gradually lost its emotive appeal in Australia concerned the rise of formal racial equality in Australia in the 1960s and 1970s. While it had been decades since racial criteria had been allowed to be used to determine whether "alien" immigrants to Australia would be awarded British subjecthood, the existence of racist laws and immigration practices in Australia had long governed on strictly racial grounds whether people could come to Australia and what legal status people in Australia enjoyed. While there were a small percentage of non-white British subjects in Australia (people who were born in Australia, or who had managed to immigrate to Australia and who already possessed or gained British subject status), Australian immigration laws and practices ensured this number remained relatively small, and other laws ensured that people in this category often had a subservient legal status. The relatively small percentage of non-white British subjects, whose legal status was often in any case diminished, did not upset the sense in which British subjecthood connoted membership of a (largely) white British race.

The removal of overt racial discrimination from Australia's immigration laws and practices, and from other domestic legislation, spelt an end for these two ways of privileging whiteness and, I would argue, Britishness in Australia. No longer would race strictly determine entry into Australia, and no longer would it be the sole cause within Australia of legal inferiority. While British subject status may long have had limited legal significance, one of the reasons why it lost its emotive appeal is thus because the advent of formal racial equality made it increasingly difficult for Australians to view themselves in any meaningful way as part of a displaced white British family. They were something else.

\footnotetext{
Notes:

1

This article was originally presented as a paper at the conference "The End of the Affair? Australia and Britain, 1945-75" hosted by the Menzies Centre for Australian Studies, King's College London, in July 2002. I thank the participants at the conference for their various comments and recommendations.

Edmund Gregory, Narrative of James Murrells' (“Jemmy Morrill”) Seventeen Years' Exile Among the Wild Blacks of North Queensland [...] (Brisbane, 1896), pp. 28-9; David Malouf, Remembering Babylon (London, 1994), see pp. 3, 202.

Calvin's Case, English Reports, Vol. 77, 1608, pp. 397, 399. See John Chesterman and Brian Galligan, eds, Defining Australian Citizenship: Selected Documents (Melbourne, 1999), p. 26.

4 \& 5 Victoriae No. 5 (Western Australia, 1841). See Chesterman and Galligan, eds, Defining Australian Citizenship, p. 42.

5

Naturalization Act 1903 (Cth), section 8.

"Opinion By Geoffrey Sawer", 26 July 1961, Appendix III to the "Report from the Select Committee on Voting Rights of Aborigines, part one", Commonwealth Parliamentary Papers, 1961, Vol. 2, p. 37.

Naturalization Act 1903 (Cth), section 5.
} 
Nationality Act 1920 (Cth), sections 7, 11.

See further Chesterman and Galligan, eds, Defining Australian Citizenship, pp. 54-6.

Commonwealth Parliamentary Debates (CPD), Senate, vol. 14, 1 July 1903, p. 1607.

Commonwealth Franchise Act 1902, section 3.

12 13

Commonwealth Electoral Act 1918, section 39 (5).

Commonwealth Electoral (War-time) Act 1917, section 10.

See further John Chesterman and Brian Galligan, Citizens without Rights: Aborigines and

Australian Citizenship (Melbourne, 1997), pp. 105-6, 162. "Opinion By Geoffrey Sawer”. See also Chesterman and Galligan, Citizens without Rights, pp. 81-2. 16

Immigration Act 1901-1949 (Cth), section 8AA; Crimes Act 1914-1950 (Cth), section 30C. See Chesterman and Galligan, eds, Defining Australian Citizenship, pp. 58-9.

Markwald v Attorney-General, Chancery Division, 1920, Vol. 1, pp. 348, 370.

Nationality and Citizenship Act 1948 (Cth), section 7.

CPD, Representatives, Vol. 198, 30 September 1948, p. 1060.

${ }^{20}$ See CPD, Representatives, Vol. 200, 23 November 1948, pp. 3300-1.

Letter from Attorney-General Garfield Barwick to Paul Hasluck, Minister for Territories, 16 July 1959, A432/81, 1966/3171, National Archives of Australia (NAA).

Nationality and Citizenship Act 1948 (Cth), sections 12 to 16. 23

See further John Chesterman, “Defending Australia's Reputation: How Indigenous Australians Won Civil Rights, Part One", Australian Historical Studies, Vol. 32, 1 (2001), pp. 20-39; and idem, "Defending Australia's Reputation: How Indigenous Australians Won Civil Rights, Part Two", Australian Historical Studies, Vol. 32, 2 (2001), pp. 201-221.

Chesterman and Galligan, Citizens without Rights.

Letter from Department of External Affairs to Australian Diplomatic Posts, 12 January 1962 , A1838/2, 557/2 part 3, NAA. See also Chesterman, "Defending Australia's Reputation, Part One”, pp. 34-5; Chesterman and Galligan, Citizens without Rights, p. 161.

See Stephen Alomes, A Nation at Last? The Changing Character of Australian Nationalism 1880 1988 (Sydney, 1988), pp. 114-17; David Day, The Great Betrayal: Britain, Australia and the Onset of the Pacific War 1939-42 (Sydney, 1988); Stuart Ward, "Sentiment and Self-interest: The Imperial Ideal in Anglo-Australian Commercial Culture”, Australian Historical Studies, Vol. 32, 1 (2001), pp. 91-108. See also Neville Meaney, "Britishness and Australian Identity: The Problem of Nationalism in Australian History and Historiography”, Australian Historical Studies, Vol. 32, 1 (2001), pp. 76, 90.

27 Stuart Ward, “Fellow Britons?”, Meanjin, Vol. 63, 3 (2004), pp. 60-62.

28

My thanks to the editors for raising these points with me.

See Chesterman, “Defending Australia's Reputation, Part One”.

See Andrew Markus, Australian Race Relations 1788-1993 (Sydney, 1994), pp. 178-80, 185-6, 190 .

31

See Chesterman, "Defending Australia's Reputation, Part Two”.

Australian Citizenship Amendment Act 1984 (Cth), section 7.

CPD, Representatives, Vol. 134, 7 December 1983, pp. 3367-8.

${ }_{35}$ Passports Act 1938-1973 (Cth), section 7; Passports Amendment Act 1984 (Cth), section 4.

Statute Law (Miscellaneous Amendments) Act 1981 (Cth), section 32; Statute Law

(Miscellaneous Provisions) Act (No. 2) 1985 (Cth), Schedule 1. The current law is to be found in Commonwealth Electoral Act 1918, section 93.

James Jupp, "From New Britannia to Foreign Power: The Decline of British Immigration", paper presented to the "End of the Affair" Conference, King's College London, July 2002, p. 7. I am grateful to James Jupp for his comments about this provision during discussion at this conference.

Sue v Hill, Commonwealth Law Reports, 1999, Vol. 199, pp. 462ff. The earlier case of Sykes v Cleary also contained consideration of dual citizenship (in this case Australian/Swiss and Australian/Greek citizenship) in the context of section 44 of the Constitution: Commonwealth Law Reports, 1992, Vol. 176, pp. 77ff. 



\section{University Library}

- MINERVA A gateway to Melbourne's research publications

Minerva Access is the Institutional Repository of The University of Melbourne

Author/s:

CHESTERMAN, JOHN

Title:

Natural-born subjects? Race and British subjecthood in Australia

Date:

2005

Citation:

Chesterman, J. (2005). Natural-born subjects? Race and British subjecthood in Australia. Australian Journal of Politics and History, 51(1), 30-39.

Publication Status:

Published

Persistent Link:

http://hdl.handle.net/11343/34428

File Description:

Natural-born subjects? Race and British subjecthood in Australia 


\section{University Library}

\section{- M M N E R VA A gateway to Melbourne's research publications}

Minerva Access is the Institutional Repository of The University of Melbourne

Author/s:

Chesterman, J

Title:

Natural-born subjects? Race and British subjecthood in Australia

Date:

2005-03-01

Citation:

Chesterman, J. (2005). Natural-born subjects? Race and British subjecthood in Australia. Australian Journal of Politics and History, 51 (1), pp.30-39. https://doi.org/10.1111/ j.1467-8497.2005.00358.x.

Persistent Link:

http://hdl.handle.net/11343/28577 